\title{
Security and border walls/fences in contemporary International Law
}

\author{
Ina SILINASDEFRí AS
}

\begin{abstract}
1bstract: The fortification of state borders with walls and the but use of law-making power and the adjudicating power of domestic courts to prevent the movement of persons - in particular those in need of protection and mainly on grounds of national security - are increasingly common in contemporary international societs. This new trend is sending a troubling message to the international community about what is permitted with regard to third countries and which human rights are protected and to what event, if at all. For states, border walls reinforce a unilateral view of international relations and international law. For people, they presage a dramatic decline in human rights protection standards. In all cases, this trend ignores the values of international law.
\end{abstract}

Kevwords: borderwall - border fences - immigration law - human rights - criminalisation - US-Mevicowall - Israeliwall - ECIIIR

\section{(1) INTROD)LCTIO)}

The construction of walls or fortified fences between neighbouring states to delimit and even more clearly separate their respective territories has become an increasingly popular and widespread practice amongst states in the last wwo decades. Itowever, although the topic has been studied in a variety of disciplines, ranging from sociology' and anthropology ${ }^{2}$ to history ${ }^{3}$, economics'and political science, ${ }^{3}$ it has not yet been practically examined from an international law perspective.

Walls and fences alter not only the relations between the states on either side of them, but also several essential flows (of goods, services, people, ideas, cultures, etc.) that, under normal circumstances, take place between them. As an intrusive material reality in international relations the existence of which affects the ontology and physiology of contemporary international sociely and relations in it, they are per se a material element that warrants consideration and, where applicable, legal regulation beyond the domestic legal system of the state that builds them. These walls may be built solely on territory clearly belonging to one

a Irlicle published on.31 December 2org

Professor of Public International Law and International Relations, L niversity of Málaga, Spain (asalinas a uma.es). This paper is a research outreach initiative made possible with funding from the Spanish Vinistry of Economy and Competitiveness (Project Ref. DER2or-65 86 R: "Walls in Contemporary International Law: Effects on Security, Iluman Dignity and Sustainability") and the Jean Vonnet "Globalizing the Union's Debate: Internal and External Leadership in an Era of Challenges EL GLOB LL" (Project Ref. 599757-EPP-1-2018-1-ES-EPPJVO-PROJECT).

' See W. Brown, II alled Slales, II aning Sovereigny (VIT Press Books, 201/).

2 See P. Gulasekaram, 'Subnational Immigration Regulation and the Pursuit of Cultural Cohesion', 77 Iniversily of Cincinnali Law Review (2008-2009), available here.

3 See M. Baud and W. Y an Schendel, 'Towards a Comparalive Ilistory of Borderlands', 8.Journal of WI orld II islory (1997) 211-2/2 |doi: hllps: doi.org 10.1353 jwh.2005.0061|.

4 See M. Sur, Through Vetal Fences: Material Mobility and the Politics of Transnationality at Borders', 8 Vobilities (2013-1)70-89 |ht1ps: doi.org 10.1080 17/50101.2012.747778|.

5 See T. Kuran, 'Availability Cascades and Risk Regulation', University of Chicago Public Law and Legal Theory Working Paper $\mathrm{V}_{0.18} 8_{1}(2007)$, available here. 
state or on a territory disputed by two or more states; they may be "porous" walls, walls with ports of entry enabling only controlled movement through checkpoints once certain administrative requirements have been met, or entirely hermetic walls. In all cases, by definition, they serve to separate when not outright isolate. Moreover, given their markedly territorial nature in the context of "deterritorialization" entailed by globalization, they are destined to spark disputes and conflicts.

The numbers support this concern. On average, there were 6,ooo kilometres of walled borders around the world in the first decade of the new millennium, equal to more than half the Earth's diameter. Additionally, more than $80 \%$ of those walls were built after 1989 , a watershed vear precisely because it was the year the Berlin Wall fell. ${ }^{6}$ In the vears since, and despite the predic lions that the world would gradually become increasingly border-free, some of the countries often described as the world's oldest democracies have contributed decisively to the number of security "barriers", erecting them along their political borders. This raises the question of why, nearly thirty years after the fall of the Berlin W all, these historical and, in theory, exemplary democracies are engaging in the mass construction of walls to separate themselves from their neighbours across the border.

In addition to these physical walls, the number of intangible walls is also on the rise, i.e. incorporeal barriers that nevertheless have the same effects as physical walls, particularly with regard to the movement of people and, quile especially, of vulnerable groups and individuals who, seeking protection, must leave their homes, crossing land or sea borders.

The truth is that these tangible and intangible barriers exist and are mushrooming across the current international geographical, political and legal landscape. Furthermore, in the case of the tangible barriers, not only has their physical existence yet to be clearly established and regulated in the international legal order, it also patently influences at least wo essential areas thereof: security, both national and international, insofar as it is the main argument prompting states to build and expand these barriers; 7 and

6. See, for example, the walls separating Pakistan and Afghanistan (2007); Iran and Pakistan (2007); Uzbekistan and Kvrgyzstan (2009); Myanmar and Bangladesh (2009); Egypt and Gaza (2009); Israel and Egypt (2010); Iraq and Syria (2010); Greece and Turkey (2011); and Azerbaijan and Armenia (2011); as well as the walls between Israel/Lebanon (200o), Uzbekistan Afghanistan (2001), and Turkmenistan U zbekistan (2001); the sadly famous Israeli wall enclosing the Palestinian territories (2002); the wall separating India and Bangladesh (2002); the wall between China and Jorth Korea (2003); the fortified fence separating Botswana from Zimbabwe (2003); the far from peaceful fortified security fence between the two nuclear powers of India and Pakistan (2003); the wall separating and isolating Saudi Arabia from Yemen (2003); the wall between India and Mvanmar (200/); the wall constructed between Thailand and Malassia (200/); the wall built by Kuwait to defend itself against Iraq (200/) after the Irapi aggression in ı99; the fence separating Brunei from Malavsia (2005); the wall built between the United Arab Emirates and Oman (2005); or the three extremelv important wall initiatives under construction since 2006 consisting of the wall between Mexico and the $\mathrm{S}$ S, the wall separating and isolating Saudi Arabia from Iraq (in fact, it seals the entire Saudi perimeter), and the wall separating Z zbekistan from Kazakhstan, although in truth the former has decided to wall itself in and isolate itself from all its neighbours, not just Kazakhstan. All of that is in addition to such flagrant historical situations as the "Green Line" dividing Cyprus (1979); the wall built by South Nfrica to seal its border with Mozambique (r97.j); the wall built by Moroceo with the IVestern Sahara (1980); or the Ceuta and Melilla walls (1998, overhauled in 2007$)$.

7 See, amongst others, the following walls: Saudi Arabia-Iraq; Brunei-Thailand; Brunei-Malavsia; India-Pakistan; North Ireland-Belfast; Israel-Palestine; and Kuwait-Iraq. W ith regard to this last example, see: A. Alderson, 'Iraq and Its Borders’, I53 The RU SI Journal (2008-2)18-22 [doi: hllps: doi.org 10.1080 03071840802103181); and S. Oluic, 'Iraq's Porous Frontiers, Internal Struggles and Fragile Statehood', 4 Journal of Applied Security Research (2009-3) 279-29o |doi: h11ps: doi.org 10.1080/19361610902930063). 
personal dignity and respect for human rights and fundamental freedoms, which are curtailed by these walls, when not openly ignored or denied, and, thus, victims of their proliferation. Indeed, the physical presence of these walls affects three basic concepts of contemporary international law: the concept of security; the concept of border; and the concept of jurisdiction.

This article will not address the concept of security, as it has been widely examined elsewhere in the Spanish literature. ${ }^{8}$ Nevertheless, it is worth recalling that current security threats are widely considered to stem from transnational realities that can only be effectively addressed through inter-state cooperation, as evidenced by the fights against organized crime, international terrorism, the criminal use of new technologies or environmental threats. It is thus surprising that states use the concept of security precisely to pursue unilateral actions and establish obstacles to international cooperation. In this regard, the names given to some of the legal instruments that states have adopted are telling, as they stress the idea of security as the grounds for establishing tangible or intangible barriers.?

Regarding the concept of border, this article will simply make wo brief clarifications in relation to the issue at hand. First, there is an insistence on conceiving of borders as a place for confrontation rather than cooperation and correlation. Second, states are pushing their borders beyond their land territory. Itence, in its effort to cope with the massive flows of people in the Mediterranean, the EU has sought to establish "early interception" mechanisms, thereby redefining its external borders." Likewise, in the executive orders of 2017, the US government established jurisdiction by US authorities over areas up to roo miles deep along the outer face of the wall separating the US and Mexico." In so doing, it encroached on the adjacent state's land territory and maritime zones, affecting its jurisdiction over them. It moreover unilaterally established obligations for third states with regard to any migrants who might reach their territory, creating what has come to be called a "borderland" rather than a borderline.

Jurisdiction is the underlying idea conditioning the effects of walls on states and people. It also underlies both the state-centric (C) and anthropocentric (D) views of walls. This paper will examine both aspects, following an analy sis of the material reality of these walls (B).

(B) W ILLS IVD FE \CES:THESU DDE IRRU PTIO\ OF M ITERI ILIZED BORDERS

8 For further information on all points, see C. García and A.J. Rodrigo (eds.), La seguridad compromelida. Vuevos desafíos, amenazas y confliclos armados (Tecnos, Madrid, 2008).

9 See, amongst others Regulation (EU) $\mathrm{N}_{010}{ }_{2}^{2} 2013$ of the European Parliament and of the Council of 22 October 2013 (Eurosur) (O.J L 295, 6 Vovember 2013, p. 11-26), or the lwo executive orders issued by Trump upon laking office on 25 January 2017, namely, the Execulive Order on Border Securily and Immigralion Enforcement Improvements and the Execulive Order Enhancing Public Safelv in the Interior of the I niled Stales, both of which cited the security of the United States.

10 As noted by A. del V alle Gálvez, who spoke in this case of "pre-border" ("prefonterizo”) control. See A. del Valle Gálvez, 'Los refugiados, las fronteras exteriores y la evolución del concepto de frontera internacional (editorial)', „jj RI)CE (SeptemberDecember 2016) 759-777, available here.

" See NII I American Immigration Council, 'Summary and Analssis of Executive Order "Border Security and Immigration Enforcement Improvements', 2 January 2017, NIL A Doc. No. 17012 „5 , at 6. In the same regard, see J. V. IJeyman, 'Construcling a Virtual Wall: Race and Citizenship in U.S.-Mexico Border Policing', jo (3). Journal of the Southwest (Aulumn 2008) 305-334 |doi: hllps:/ doi.org I0.13j3 jsw.2008.00ı0|. 
Traditionally, the construction of walls reflected the aspirations of cily-states, kingdoms, nations, empires or modern states to consolidate and stabilize their respective territories. They were thus a means of isolation and defence in intrinsically violent societies in which war and the right of conquest were legal and, because of that possibility of acquiring territory, borders were mobile.

However, the global nature of today's international society, its obligatory peaceful co-existence, and the globalization undergone in recent decades would seem to run contrary to this growing trend of building border walls, let alone of doing so in violation of international law.'2 It is thus both surprising and troubling that, whilst at the time of the demolition of the Berlin Wall, the most ideological wall of them all, there were 19 walls between states, today there are almost go. Furthermore, whilst that wall was intended to keep people in, "3 those being built today are basically intended to do the opposite, i.e. to keep people out.'i And this wall-building trend spans the whole planet. Similar examples can be found on all continents, which seem to be immersed in a genuine process of being "parcelled up". This is in addition to the existence of internal walls in some states, built to further consolidate economic and social inequality. ${ }^{5}$

Although the states building these barriers cite a variety of reasons, one in particular stands out, or, perhaps, encapsulates all the others in a single idée-force or snapshot: the defence of national security, which justifies not only the extraterritorial application of purely domestic laws beyond the borders of the state in question, but also even an abusive use of that state's jurisdiction. If fortification was once important in terms of defence, such devices do little to nothing to address today's security threats. These new architectural barriers are actually an attempt to restrict and control the movement of people, goods and, to a lesser extent, information or even the spread of disease between states."

Modern state borders were, until recently, abstract, intangible lines that marked the boundaries of state jurisdiction in a statist and merely competence-based international law dynamic ${ }^{77}$ that today is understood to have been surpassed. ${ }^{18}$ Insofar as the study of borders was synonymous with the analysis of the lines separating states' sovereign territories, it basically focused on their demarcation, i.e. on geography. However, the materialization of borders in the form of walls, security fences, etc. calls for a global

\footnotetext{
12. See Legal Consequences of the Construction of a II all in the Occupied Palestinian Terrilory, Ad isory opinion of g.July 200/, IC.J Reports (200/), para. 121.

13 See the ECtIIR judgment of 22 March 2001 in the case Strelelz, Kessler and Krenz v. Germanv, Applications Jos.

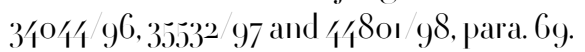

1/: See I S I Secure Fence Act of 2006 (II.R.6o61 $\quad$ log Congress (2005-2006).

5 These are the so-called "muros de la desigualdad" ("walls of inequalit") that can be found, amongst other places, in Lima, where they are used to isolate the "condominios" (blocks of flats) where the wealth live from the most imporerished neighbourhoods; Rio de Janeiro, where they are intended to isolate the "favelas"; and Posadas, on the border between Argentina and Paraguay, where they are used for the same purpose.

16 That was the reason initially cited to justify the construction of the wall between Botswana and Zimbabwe, i.e. to block the entry of FMI)-infected catle.

${ }_{7}$ See K. Raustiala, "The Geography of Justice, 73 Fordham Law Review (2005), 2501 el seq., available here.

18 See W. M. Reissman, The Quest for Morld Order and Muman Dignity in the Twentr-First Century: Constitulive Process and Individual Commitment', General Course on Public International Law, 351 RC I/)/ (2010) I-38ı, in particular, Chapter II |doi: hllps: doi.org 10.1163 $978900 / 23616 j$ |.
} 
understanding of an entire process rather than just a material element. ${ }^{19}$ That process can only be understood through a multidisciplinary analysis (geographical, sociological, political, historical, psychological, geostrategic and emironmental), ${ }^{20}$ because, as a process, it is dynamic rather than static, which makes these walls questioned, controversial or disputed areas. ${ }^{22}$

The border is dynamic not only because people and goods cross it, but also because it itself, as well as the legal system regulating its existence and/or use, is subject to all sorts of contingencies. ${ }^{23}$ This dynamic nature likewise affects the wall or fence that "symbolizes" it. That is why borders and, therefore, walls cannot be understood statically in terms of inclusion and/or exclusion, but rather must be understood dynamically in terms of movement. Consequently, it is necessary to analyse and understand them outside the binary logic of "inside/outside”, which, furthermore, can vary depending on a variety of factors, such as people who cross them illegally, the legal regulation of crossings, ete. This means that borders are unlikely to be one hundred per cent successful at keeping people in or out against their will; hence, the idea that what truly matters when it comes to organizing international society is not borders themselves, but movement across them. ${ }^{2}$ '

Vevertheless, the consequences of border walls go much further, giving rise to a series of perverse effects: a) the toughening up of national policies to control the flow of people, whether migrants or people in need of international protection, with the ensuing increase in mixed flows; b) the use of increasingly deterrent devices on fences and walls, when not devices that are manifestly contrary to people's physical integrity; c) the diversion of the routes ${ }^{25}$ that migrants follow towards other more dangerous ones, resulting in a verified increase in human-trafficking mafias; and d) breaching by states of their obligations with regard to asylum, refugees and the protection of human rights or the so-called minimum standard of treatment. This latter consequence is in addition to the breach of cooperation and good neighbour agreements and other international commitments, as well as, in the case of some European states, the breach of commitments undertaken in legally binding instruments concluded by the European institutions and even the questioning of respect for the EU's own values and principles. ${ }^{26}$

19 See C. Rumford, 'Seeing Like a Border', in C. Johnson el al.(eds.), Inlerventions on Rethinking "Ihe Border" in Border Studies, $3^{0}$ Political Geography (2011-2) 6ı-69 |doi: h11p: dx.doi.org 10.1016 j.polgeo.2011.01.002|.

20 See I). Newman, 'On Borders and Power: A Theoretical Framework', I8 Journal of Borderland Studies (2003-1) 13-2 j

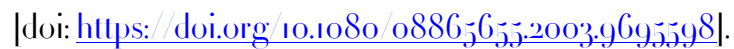

${ }^{21}$ T. Vail, Theory of the Border (O)ford University Press, 2016) at 5-6; R. T. Ford, 'Law and Borders', 6, Alabama Law Review (2012-1) 123-139, available here.

22 Ibid., al 6.

23 I. Vaughan- W illiams, Border Politics: The Limils of Sovereign Power (Edinburgh U niversily Press, 2009 ), at I.

24 See Jewman, supra 1 . 20 , at 15 .

25 See Inter- Imerican Commission on Iluman Rights, Report on Immigralion in the I niled Slates: Delention and Due Process, 2010, OE I Ser.L V/II, Doc. 78 10, $3^{0}$ December 2010. On this issue in Europe, see: A. Brouwer and J. Kumin, 'Interception and Asylum: When Migration Control and I Iuman Rights Collide', 2 ( (q) Refuge: Canada's Journal on Refugees (2003) 6-2/, available here; A. Siani, 'Interception Practices in Europe and Their Implications', 2 (4) Refuge: Canada's Journal on Refugees (2003) 25-34; and T. Spijkerboer, 'The IIuman Costs of Border Control', g European Journal of Vigralion and Law (2007) 121-139 |doi: h11ps: doi.org 10.1163 1388,6407

26 In this regard, see the letter sent by Ilungarian Prime Minister Viktor Orbán to the President of the European Commission, requesting EU funding for the fence that Itungary built on its border with Serbia on the understanding that the 
Insofar as they do not simply indicate a state's territorial boundaries - in accordance with the more classical definition of the concept of border ${ }^{27}$ - these walls become dynamic elements of social division. ${ }^{28}$ In separating two entities - not just two territories they create an intermediate place with its own significance, one that lacks, for the time being, international regulation, i.e. the wall or fence itself.29 In this sense, the border can be perceived as a place of continuation or a place of separation and regression, depending on the legal landscape that frames it. ${ }^{30}$ Itowever, fences and walls restrict or even abruptly eliminate any possibility of continuation or idea of union, amongst other things, because they can be completely devoid of ports of entry or, on the contrary, offer only checkpoints as the sole possible ports of entry or continuation between the neighbouring territories.

The ultimate reason prompting states to choose this fortified response is not easilv identifiable. However, a state's decision to fortify its borders can be seen, de facto, to vield a certain political return for the government that makes it. ${ }^{31}$ Furthermore, to the extent that it prevents social and cultural miscegenation and further closes off a population group united by a series of historical, social, cultural, legal and economic ties, it reinforces a discriminatorv national sentiment, a negative view of non-nationals, who can be considered a threat. ${ }^{32}$

In most cases, "security" narratives are used to justify the construction of walls. IIowever, in deciding to build them, governments have sought not only to erect a defensive barrier against threats from the outside world, but also to define who belongs to their respective state. They do this by encouraging citizens to create and internalize those barriers in an attempt to create a stable and homogeneous population within a perfectly defined territory, thereby legitimizing exclusionary practices. The governments of the states that act this way publick stress to their citizens that these barriers are essential tools to protect the

fence serves EU interests in general by keeping the EU free of illegal immigrants, considered to be dangerous and undesirable. (See El Paús,'I Iungría pide a la E Eque pagueparte de la valla que levantó para frenar a los inmigrantes', i September 2017.) The request was considered scandalous and accordingly denied by the EU. However, it was also accompanied by the passage of a law in the Hungarian Parliament allowing the systematic detention of any person in IIungary without a residence permit, regardless of whether they might need international protection (see El Paús, 'Itungría delendrá sistemáticamente a lodos los inmigrantes que entren sin papeles', 7 March 2017), as it would not be able to approve their application. This entailed a serious risk of breach of Art. 2 TEU, prompting the European Parliament to vole, in September 2or8, to trigger the Art. 7 TEU sanetions procedure against this Member State. The Commission responded in April 2019 with a communication on the EU and the Rule of Law. There were also serious suspicions of mistreatment, by the Hungarian authorities, of the people forming part of the massive flows that, in 2015 , were displaced to Central Europe as a result of the resurgence of the armed conflict in Syria, creating a genuine humanilarian emergencs.

${ }_{27}$ According to the Oxford Dictionary " $A$ line separating two countries, administrative divisions, or other areas".

28 See T. Nail, Theory..., supra n. 2I, at 2; I). Ilernández Joseph, 'Política migratoria y de control fronterizo de Estados Unidos hacia México y Centroamérica', I I (8) Revisla Enfoques (2008) 193-21/, available here; and J. McFadven, 'W eighing the Pros and Cons of U.S.- Mevico Border Barrier: Immigration Issue Affects Econom, Muman Lives and Message to the Morld', available here.

29 See M. Paz, 'The Law of Walls', 28 The European Journal of Inlernalional Law (2017-2), at 602 |doi: hllps: doi.org 10.1093 ejil chxo26).

$3^{\circ}$ That is, whether the border being crossed lies within the EU's Area of Freedom, Security and Justice, or the geographical context of a regional organization with some sort of agreement on matters of free movement, or between states not bound by ans commitment in this regard.

$3^{3}$ The electoral victories of Donald Trump in the $\mathbf{S}$ or, more recently, Kurz in Austria can be interpreted in this regard.

32 See P. Gulasekaram, 'Why a wall?', 2 C C Irvine Law Review (2012) 1/47-192, at 158, available here. 
ideals and freedoms that define the modern democratic state. However, the exclusion and violence exercised by these same states often undermine the ideals these measures are intended to protect and defend. The most dangerous aspect is not the wall's physical existence, but the racism it fuels between the peoples on either side, the permanent invitation it constitutes to deny the other's existence or attack it. As has been argued elsewhere, the enemy behind a wall is a "faceless enemy" who deserves to be destroyed; an enemy with a visible face is a human who deserves respect. ${ }^{33}$ On the other hand, without a walled construction, the border, as a social and legal construct, lacks emotional force. Compared to the complexity for the population of understanding government provisions regulating entry and stays in the country, the construction of a wall is easy to interpret and understand and conveys the message of an omnipresent state protecting against an external threat. 34

The field of international relations has offered a Freudian explanation for the proliferation of these walls in general, and of some virtually impossible constructions in particular, such as the border between Mexico and the US. According to this explanation, these megalomaniacal constructions are simply intended to symbolize, where applicable - especially in times of crisis - the power of the sovereign, to reaffirm a sovereignty that has been relativized and, in some ways, diminished in current international society through massive and unequivocal constructions that exalt the power of the government that builds them. ${ }^{35}$ However, walls themselves, as a new reality imposed on the relations between states, can be analy sed from a dual point of view: a state-centric perspective and an anthropocentric one, i.e. one focused on walls' effects on individuals. In the former case, the debate will centre on territoriality; in the latter, on the protection of human rights. Amongst all the possible examples, this article will primarily focus on the wall between Mexico and the $\mathrm{US},{ }^{6}{ }^{6}$ whilst also making some references to the cases of India, Israel and the EU.

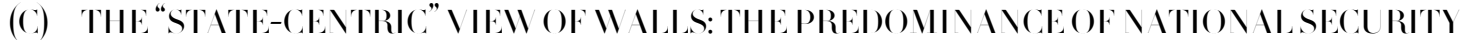

The idea that a wall is the best solution to any threat of insurgency has been common throughout history. Given the additional risks potentially posed by globalization in this regard, security-related reasons have featured prominently in justifications for the proliferation of walls or fences. This argument is based on

\footnotetext{
33 See in this regard M. Iear, II hy II alls II on't II ork: Repairing the U S- Vexico Divide (O)ford U niversity Press, 2013).

3 See Gulasekaram, supra n.32, al i 63 .

35 See D. Dorsev and M. Díaz-Barriga, 'Bevond Surveillance and Moonscapes: An Mtternative Imaginary of the U.S.-

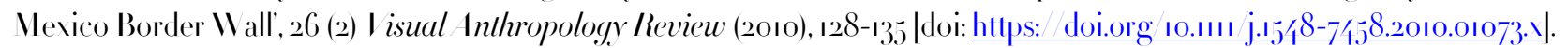

$3^{6}$ The only wall established by law, first under the Secure Fence Act (2006), and now under Execulive Order 13767 of 25 January 2017 (Federal Register, Vol. 82, Jo. 18, Mondav, 30 Januarv 2017). Section 2 (e) defines the wall as "a contiguous, phssical wall or other similarly secure, contiguous, and impassable phssical barrier", in accordance with Section 3 of the Border Security and Immigration Executive Order. Construction began on it during the presidency of Bill Clinton and has been enthusiastically resumed under the Trump administration as one of the flagship initiatives of his presidency. Vevertheless, its construction and funding have been steeped in controversy, as each mile of wall has an approximate cost of if million dollars. See Cato Journal, 'Illegal Immigration Outcomes on the U.S. Southern Border'; and S. Pierce, 'Immigration-Related Poliev Changes in the First Two Years of the Trump Administration', Migralion Policy Institule (2019), at i, available here. In the same vein, see U S 1 Today, 'President Trump's execulive actions: The complete list so far'.
} 
the understanding that the greatest threat to security is the existence of porous borders separating unstable, problematic, less developed, etc., states. ${ }^{37}$

In the rg9os, India, traditionally considered the largest democracy in Asia, was the first state to resort to the construction of a wall. This decision was compounded by the fact that the wall was built along a controversial borderline not accepted in its entirety by neighbouring Pakistan, in relation to the disputed region of Kashmir, whose inclusion in India it rejects. The fence is secured with an exclusion zone that, at some points, spans up to $5^{\circ}$ kilometres. This zone is reinforced with mines - despite the international ban on using them - and monitored by drones, in addition to being equipped with other high-tech instruments, making it an important friction point between two nuclear powers. It is expected to reach a final length of around 3,300 kilometres. $3^{8}$

India argues that the fence is an effective means of defence against threats to its security from Pakistan, in particular in the separatist areas of Punjab and Rajasthan, and it has completed more than 2,goo kilometres so far. It has used the same argument to seal its separation from Bangladesh, with whom it shares the fifth longest border in the world, which, until just a few years ago, had been only loosely controlled. The existence of that barrier leaves 100,000 people in a no-man's land devoid of basic services. However, although the figures are hard to verify, between to and 20 million Bangladeshis are illegally in India. Whilst this situation may not, at least, detract from the security-based argument, it does seem to highlight the feebleness of the border's fortification in terms of strengthening India's security.

Thus, it has been argued that the fence separating India and Bangladesh shapes and is shaped by Iwo feelings: that which holds that Islamist terrorism in India is a terrorism imported from Bangladesh; and that which understands that effective control of the border with this state is crucial to combating it. This combination results in prejudices that condition the assessment of the fence and subliminally convey the message that: a) the fence isolates these Bangladeshis because they are violent, pre-modern and irrationalism contrast to the civilized world of India; and b) India is the first line of defence in the fight against radieal and terrorist Islamism, the frontline in the struggle against international terrorism. ${ }^{39}$ Both messages encourage the population to "close ranks" and come together against a common external enemy. Israel began to build its wall to delimit or, rather, isolate the Palestinian territory in 2002, during the second Intifada, despite the lack of any previous agreement with the Palestinian Vational Authority. Some $80 \%$ of the built wall lies in the West Bank, winding through territory considered Palestinian and, therefore, not subject to annexation through its inclusion on the Israeli side of the wall. The Israeli wall or "security fence"

\footnotetext{
37 See P. Staniland, 'Defeating Transnational Insurgencies: The Best Offense Is a Good Fence', 29 The II ashinglon Quarlerly (2005-1) 21-40|doi: hllps: doi.org 10.1162 o163660057748 89698 |.

$3^{8}$ See M. Sur, 'Through Metal Fences: Material Mobility and the Politics of Transnationality at Borders', 8 Mobility (20131) 70-89 lhllps: doi.org 10.1080/17450101.2012.747778|.

39 See D. McDuie-Ra, Tribals, migrants and insurgents: security and insecurity along the India-Bangladesh border', 2/

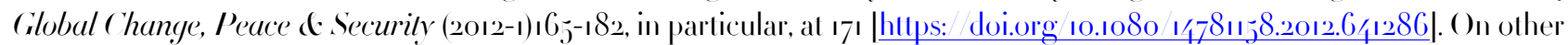
separation walls on the Indian subcontinent, see J. I). Greenberg, 'Divided Lands, Phantom Limbs: Partition in the Indian Subcontinent, Palestine, China, and Korea', ,7 Journal of Internalional 1/fairs (200/-2) 7-27, available here.
} 
is twice as high as the former Berlin $\mathbf{W}$ all and, once finished,,$^{\circ}$ will be thirty times as long. It also includes territories beyond the Green Line established as the international border prior to the Six-I)ay $\mathbf{W}$ ar of $g^{6} \mathrm{~F}$. It was argued that it would stop the Palestinian terrorist attacks that threatened the very existence of the state of Israel, which certainly were taking place. However, as has been noted elsewhere, í given how crucial the Israeli government claims that the wall is to Israel's existence as a state, the country's arguments regarding this specific rationale in the run-up to the advisory opinion rendered by the International Court of Justice in 200/were surprisingly brief.

In any case, the lack of practical effects resulting from the IC.J's emphatic advisory opinion, despite the many violations of various international obligations that the barrier entails, has been widely acknowledged and discussed in the international law literature. The Israeli Supreme Court has even refuted the opinion to a certain extent and approved the barrier's permanence - barring a few slight changes in its path in very specific areas - without those breaches having elicited any response from the international community. ${ }^{2}$

But the most important thing is that the "security" reasons used to justify its construction do not hold up today and have only served to deepen the threat against the Israeli population, not necessarily from the Palestinian population - although that, too, as the wall's construction has made the occupation of the Palestinian territories, the forced submission of their people and a growing discontent and instability in the West Bank more visible - but because it serves as a pretext for any jihadist movement wishing to embrace the Palestinian cause for its own purposes. ${ }^{3}$ It also seriously contributes to the radicalization of an impoverished, neglected and desperate Palestinian population made more sensitive and permeable to non-peaceful appeals or initiatives.

This supposed justification is even clearer in the case of the US-Mexico border wall. Since the

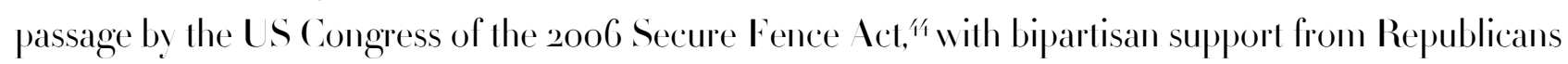

40 The wall has not vet been completed in some small areas due to the presence of obstacles, such as the two Salesian monasteries in the citv of Beit Jala.

¡ See D. Bondía García, 'Sí, señoras y señores, sí, Israel liene argumentos..., in R. Escudero Alday, Los derechos a la sombra del muro. I n castigo más para el pueblo palestino (Calarala, Madrid, 2004), al 98.

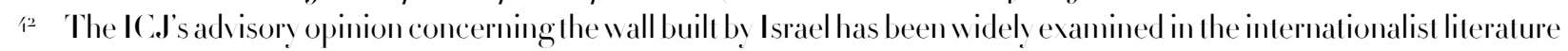
and a detailed discussion of the matter would go beyond the scope of this paper. For more information on all aspects, see: $\mathbf{A}$. Badía Martí, 'La opinión consultiva de la Corte Internacional de Justicia sobre las consecuencias jurídicas de la construcción de un muro en el territorio palestino ocupado de g de Julio de 2009, g Revisla Electrónica de Esludios Inlernacionales (200弓亏) I-23, available here; R. Escudero Nldav (ed.), Los Derechos a la Sombra del Vuro. In castigo más para el pueblo palestino (Catarata, 2006); I. Scobbie, 'Regarding Disregarding: The Judicial Rhetoric of President Barak and the International Court of Justice's Mall Akisory Opinion', j Chinese Journal of Inlernational Law (2006-2) 269-300 |doi: hllps: doi.org 10.1093 chinesejil jmlo2I|; I. M. Gross, 'I Iuman Proportions: Are Iluman Rights the Emperor's Vew Clothes of the International Law of Occupation?', is European Journal of Inlernational Law (2007-1) 1-35 |doi: hllps: doi.org 10.1093 ejil chmool); and M. Burgis, 'I Discourses of Division: Law, Polities and the IC.J Ad isory Opinion on the Legal Consequences of the Construction of a $\mathbf{W}$ all in the Occupied Palestinian Territory', 7 Chinese Journal of International Law (2008-1) 33-63 |htlps:/ doi.org 10.1093 chinesejil jummo/40|.

13. The Palestinian cause has often been invoked by terrorists who supposedly support it, as well as by members of Daesh in recent terrorist attacks carried out on European soil, including two of the London attacks and one of the attacks carried out in Paris.

化 Available at hllps: www.govtrack.us congress bills log hr6o6ı. 
and Democrats, , o8o kilometres of mixed barrier - consisting of concrete, barbed wire, patrolled roads, fences and high-tech "smart border" areas monitored by sophisticated equipment such as unmanned aireraft - have been completed. Originally devised by Bill Clinton, it became another of the George WI. Bush administration's key initiatives to secure the country against the terrorist threat in the wake of the sad altacks of us September 2001.

As powerful as the arguments concerning the "war on terrorism" and the Bush doctrine of "preventive war", aimed at destroying the foreign enemy and strengthening domestic security in order to prevent individuals from countries deemed wild and uncivilized from entering the country, are, they do not, in themselves, explain the construction of these barriers. They do, however, strongly contribute to describing and defining neighbouring peoples as inhuman and undeserving of the modern human rights guaranteed by democracies, thereby transforming the respective walls into the boundaries of the modern world, beyond whose borders lies only chaos.

The truth is that the strictly "security"-based conception of that border following the 200 attacks has proven wrong in at least three ways. First, the wall's construction has not reduced migratory pressure from the south, as evidenced by its inability to prevent the entry of migrants from Mexico. ${ }^{6}$ On the contrary, a 2008 Congressional Research Service report expressly stated, "There is considerable evidence that the flow of illegal immigration has adapted to this enforeement posture and has shifted to more remote areas of the Arizona desert." ${ }^{17}$ Second, the application of this prevailing view of security and the terrorist threat to border control has reduced the control of other very important forms of transnational organized crime,

4. For background on this initiative, see D. Gilman, Obstrucling Iluman Rights: The Texas- Mevico Border Wall. The Working Group on I Iuman Rights and the Border Wall, Background and Contexl', June 2008.

40. See Gulasekaram, II hy a wall..., supra n. 32 , at ${ }_{5} 6$.

17 See CRS Reporl for Congress. Border Securily: Barriers Llong the U.S. International Border, updated iz May 2008 , at I, available here. The US Accountability Office later made the same assertion, noting that the wall had been breached 3.363 times and that it has not yet found any way to determine whether the fence was helping to halt illegal immigration. Reported in T. \ail,

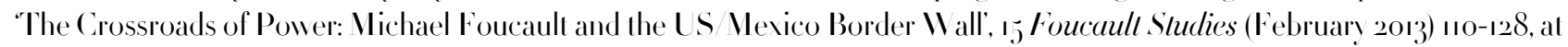
II6 |doi: hllps: doi.org 10.22/39 fs.voiry3993|. For the full report, see US Government Accountability Office, "Technology Deployment Delays Persist and the Impact of Border Fencing I Ias Jot Been Assessed' (2009). 
as has repeatedly been made clear. ${ }^{8}$ Finally, third, it has had a tremendous impact in terms of human rights violations, ${ }^{19}$ as will be discussed in the following section.

The "Border Security and Immigration Enforcement Improvements" executive order issued by President Trump at the start of his term of office seeks to implement an even stronger vision of the "insecurity" involved in allowing people to flow across that border. Based on the idea that people who enter US territory illegally "present a significant threat to national security and public safely", its main purpose is "to detain individuals on mere suspicion of violating the law, including immigration law", to which end it criminalizes, purely and simply, undeclared immigration. ${ }^{50}$

The Trump Administration has taken a series of additional steps that clearly affect the exercise of sovereignty by some states. First, not only does it exercise U S jurisdiction over an adjacent foreign territory up to too miles deep, it has also identified and cut all kinds of aid, assistance and cooperation funding to cities deemed uncooperative in the fight against illegal immigration ("sanctuary cities").j Second, it has

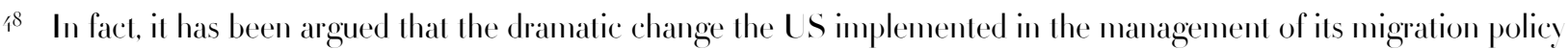
following the 200 atlacks with regard to management of the border with Mexico has encouraged the border's militarization in favour of security rather than the fight against illegal immigration and forms of organized crime such as drug traffiching. See A. M. Bustamante, 'The Impact of Post-9 n US Policy on the California-Baja California Border Region', 28 Journal of Borderland Studies (2013-3)307-320 |doi: hllps: doi.org 10.1080 0886j6jz.2012.7j172g|; and I). Shirk, 'Law enforcement and security challenges in the U.S.-Mexican border region', 18 Journal of Borderland Studies (2003-2) 1-2/ |doi:

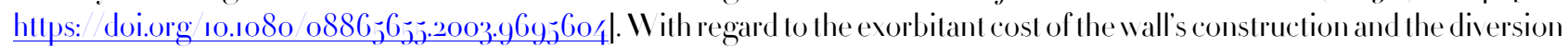
of resources for this purpose and, therefore, the weakening of the fight against other criminal phenomena, see D. Kerwin, From IIRIR $\backslash$ to Trump: Connecting the Dots of the Current U S Immigration Poliey Crisis', 6 (3).Journal on Vigration and I/Luman Securily (2018) 192-20/4 |doi: hllps: doi.org 10.1177 2331502/18786718|. The government's failure to demonstrate that the existence of the physical wall prevents the entry of potential terrorists, who, in any case, did not enter by land but by air in 2001 and are more likely to cross the border with Canada, which is much less heavily monitored, than the border with Mexico, has

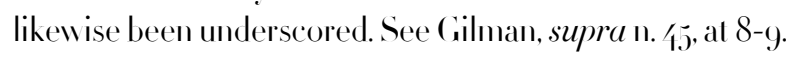

19 In this regard, see D. Gilman, 'Seeking Breaches in the Wall: An International Human Rights Law Challenge to the Texas- Mexico Border W all', 96 Texas Inlernational Law Journal (2011) 257-293; Amnistía Internacional: Enfrentando Muros. Violaciones de los derechos de los solicitantes de asilo en Estados Unidos y México', 2orz; and IIarvard Immigration and Refugee Clinical Program, 'The Impact of President Trump’s Eveculive Orders on Asvlum Seekers', Ilarvard Law School. Similarly, the fact that the border fence encroaches on and owned by indigenous peoples, causing harm to them and to their right to move freely and hindering the normal functioning of family ties, has been denounced before the Inter- Imerican Commission on Ituman Rights. Ilowever, that body could only take note of this fact, as the US is not a party to the American Convention on I Iuman Rights and, consequently, the Inter-American Court has no adjudicatory power over it. See 'I ICIIR Expresses Concern over Execulive Orders on Immigration and Refugees in the United States, available here.

$5^{\circ}$ See American Immigration Council, Summary and Analvsis..., supra n..I; and The New York: Times, Trump's Immigration Order Eypands the Definition of "Criminal", 26 January 2017, despite the fact that, according to the figures offered by the Migration Policy Institute, a nonpartisan think tank, of the it million undocumented immigrants in the country, only 820,000 have a criminal record and the number of entries across the southern border has declined dramaticalls (Cato Journal, 'Illegal Immigration Outcomes on the U.S. Southern Border'; CBP Border Security Report, Fiscal Year 2017, 5 December 2017. IIomeland Security Department). In any case, according to the Trump administration, the aim would be to protect US workers and taxpayers (see Testimony of Ronald D). Vitiello, Acting Depuly Commissioner U.S. Customs and Border Protection before the U.S. I House of Representalives, Committee on Homeland Security, Subcommiltee on Border and Maritime Security, on 'Stopping the Daily Border Caravan: Time to Build a Poliey Wall', 22 May 2018, Washington D.C.; and Testimony of Carla Provost, Acting Chief, U.S. Border Patrol, U.S. Customs and Border Protection, U.S. Department of Ilomeland Security, before the U.S. Senate Committee on the Judiciary, on The MS-13 Problem: Investigating Gang Membership, Its Vexus io Illegal Immigration, and Federal Efforts to End the Threat', 2 June 2017, W ashington I).C.).

$5^{\prime} \quad$ See S. Pierce, supra n. $3^{6}$, al 6 . 
unilaterally determined that the bordering countries of Mexico and Canada must keep within their territories and under control any migrants seeking to apply for asylum or any other type of protection whilst their claims are being summarily studied. ${ }^{5^{2}}$ This list has recently been expanded to include Guatemala, as a country of origin and, especially, transit for immigrants, following threats and the exertion of enormous pressure on that country.33 Third, it has dramatically cut - when not outright eliminated economic aid to the Central American countries from which most of the immigrants trving to cross into the US come, accusing them of not cooperating enough to prevent these people from leaving their countries of origin. ${ }^{51}$ And, fourth, in addition to imposing the so-called "seven-country ban" (affecting seven Muslim-majority countries, a measure reminiscent of the discriminatory practice of profiling), whereby it automatically denies visas to nationals of the seven countries included in the ban, the administration has increasingly pressured at least 23 countries to accept the return and repatriation of their nationals from the US.5.5

As for the EU, the images evoked thus far of walls built in the Americas, Africa or Asia on the grounds of a national situation of extreme peril due to potential, imminent or consummated terrorist atlacks, the actions of insurgent groups, or proximity to other states embroiled in any kind of armed conflict would have seemed remote had the armed conflict in Syria not spilled out into its neighbouring countries and, especially, Europe. The more or less apathetic altitude of European states as a whole - with the honourable exceptions of a few that have been victims of major terrorist attacks since n September and of the EU itself might have continued for some time more had it not been for the existence of an armed conflict set off in Europe's immediate external surroundings. The mutation of the failed Syrian Arab Spring into an armed conflict, coupled with the rise of terrorist groups with unprecedented territorial control, resulted in a mass outflow of people in search of protection. They were joined by those seeking better living conditions in Europe, resulting in mixed flows on a scale not seen on the continent since World War II and which have been a boon to human trafficking mafias.

The hegemony of the defence of security and the national interest above all other considerations became especially visible in Europe when the phenomenon of foreign combatant terrorists emerged on the Old Continent. Until then, the predominant concern had been migration control. The emergence of this new facet of the terrorist phenomenon and its irruption into Europe underscored the vulnerability of the European population. The Syrian conflict and the escalation of terrorism in Europe became the justification for reducing protection, although the cases in which someone meriting international protection has actually helped to commit any of the atlacks occurring on European soil since 201/4 have, to

$5^{2}$ See Section 7 of the Executive Order under the heading "Return to Territorv".

33 See El Paús, 'Guatemala cede a las amenazas de Donald Trump y acepta recibir más refugiados', 27 Julv 2019 . This agreement, which the wo administrations negotiated in secret, exacerbates the situation in Guatemala, which is neither a safe third country for asy lum seekers nor a government capable of successfully managing huge numbers of immigrants. See The II ashinglon Post, 'Guatemala's migrant pact with the U.S. threatens to unleash a political crises', 27 July 2019.

3 See El Pás,Trump ordena cortar la avuda exterior a Centroamérica como protesta por la migración de familias';

March 2019 .

5. See S. Pierce, supra n. 36, al 8-9. 
date, been scarce.$^{-6}$ Ilowever, the number of people trying to reach the safety of Europe by land, sea or air has skyrocketed, despite the dramatic number of victims, ${ }^{57}$ showing that, as in the previous case, the construction of walls of any kind has not proven to be an especially useful remedy. In contrast, the toughening of controls, i.e. the intangible barriers, has caused the preferred migration routes to Europe to shift to more hostile territories of departure and much more dangerous migration routes controlled by mafias and violent groups..$^{8}$

The provisions specifically designed to fight this scourge at the European level ${ }^{59}$ have not met with excessive enthusiasm from the European states, which are reluctant to embrace them. ${ }^{60}$ However, the mechanisms they provide for to combat those supposed security risks do not include border closures, let alone border fortification, but rather more efficient forms of preventive cooperation.

In any case, the state-centric vision of walls inevitably leads to a new reflection concerning the concept of jurisdiction, closely linked to the concept of sovereignty, insofar as the currently prevailing concept of sovereignty as a progressively restricted state attribute leads to the conception of jurisdiction not only as a state "regulatory power", but also a state "regulatory and adjudicating duly", i.e. a range of circumstances owed not only to other states but also to private parties. This idea is best known in the context of criminal law obligations, as recalled elsewhere, and also in the context of obligations to protect human rights, ${ }^{61}$ in particular, the rights to due process and redress and to counter any denial of justice, as will be seen below.

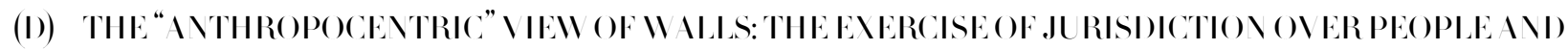

\section{RESPECTFORIIU MII RIGITS}

$5^{6}$ They would include the cases of Salmon Abedi, the perpetrator of the Manchester Arena bombing on 22 May 2017 , a Libvan refugee; the Morocean man who stabbed several women in August 2017 in Turku, Finland; the Palestinian refugee who attacked several people in a supermarket in I Iamburg on 27 July 2017; or the Irapi refugee behind the attack on the London Underground in Seplember 2017.

${ }_{57}$ The IO M's statisties on people who have disappeared or lost their lives trying to reach Europe are harrowing, reaching more than 2,700 people in 2017 alone.

$5^{8}$ See Spijkerboer, supra n. 25, 13/-136. In the same regard and in relation to migration to the US, see Amnistía Internacional, supra n. 49, al 7 .

59) See, in particular, the Additional Protocol to the Council of Europe Convention on the Prevention of Terrorism, CETS Vo. 217. Thus, to continue the negotiation of the Riga Protocol and open it to ratification by the EU as well, which had already signalled its willingness to sign it on behalf of the 28 Member States, the $\mathbf{~ K}$ demanded that it include an opt-out clause, as ratification of the Additional Protocol entailed ratification of the Convention on Prevention itself, and the U K did not wish to ratifi either. Spain is the onl European state to be condemned by its own courts for lack of diligence in compling with the processing of astum applications submitted by people fleeing in the midst of the Mediterranean crisis. Spain failed to fulfil this obligation, including in relation to those applications enforceable under the established community quota. Specifically, the Spanish Supreme Court concluded that Spain had not met its obligations to process refugee applications according to the quota imposed by the EU in Julv 2018. See Supreme Court judgment n68/2018, of 9 Julv 2018.

6o To date, only the following countries have ratified the Protocol: Albania, Bosnia-Ilerzegovina, the Czech Republic, Denmark, France, Slovakia, Itungary, Italy, Latvia, Lithuania, Monaco, Montenegro, Portugal, the Republic of Moldova, Sweden and Turkev.

6. See A. Vills, 'Rethinking Jurisdiction in International Law', 8/ (I) BYIL (201/) 187-230 |doi: hllps: doi.org 10.1093 bybil bruoogl. 
Walls thus fulfil a dual purpose: to delimit the territory and reinforee the border, on the one hand, and to prevent the entry of non-nationals, such as immigrants or people seeking protection, on the other. In accordance with this dual conception, walls can give rise to discrepancies regarding territorial delimitation between states and its more or less legal nature, which is not a minor issue. Ilowever, just as walls close off a portion of territory as a manifestation of the physical space in which a state exercises its sovereignty and jurisdiction, they also divide population groups both inside and outside of them.

The flipside of this understanding of walls from an exclusively state-centric perspective, focusing on states' territoriality and sovereignty, is the impact that walls have on individuals. The contrast here is clear: whilst in contemporary international law, borders, once established, are static, from an anthropocentric perspective, walls affect groups of people who are, by definition, mobile, making them an evolving element rather than a static one. The mere presence of a separation wall or fence between states violates this mobility and organizes it in a certain way. Additionally, this presence serves to organize population groups according to criteria decided by the state, and even to impose a certain "discipline" on groups of people deemed problematic by systematizing their mobility. ${ }^{6}$

Of the various actions border states can carry out in relation to people, the exercise of jurisdiction beyond the border, wall or fence in question, and its impact on the enjoyment of rights, especially fundamental rights and freedoms, when the holders of those rights are individuals who are not part of the state's intramural population, are not nationals of the state and are trying to exercise their right of movement (immigrants) or seeking protection as a result of persecution by their own state (refugees and/or asylum seekers), seem especially important.

Because, even though the wo aforementioned cases - migrants and asylum-seekers refugees are radically different, the wo groups merge when they move, leading to a certain osmosis in terms of the protection of human rights. Faced with the arrival of a mixed flow, states thus have the obligation to, at least, allow each incoming person to seek to prove his or her need for protection, over which, as the territorial state, they will then have decision-making power. When those waves of people become massive as a result of major natural or human disasters, systematic violence within a state, or, especially, long and intense conflicts, states tend to reject this type of inflow, using physical walls and also the restriclive interpretation and application of existing regulations or creation of new ones to stop the waves. In this situation, in light of the virtually non-existent protection of the fundamental rights of undocumented workers, ${ }^{6}$ international law offers a solid protection device to refugees and asylum-seekers, so all members of such groups of displaced peoples will seek to claim this benefit. International case law concerns two different phenomena: on the one hand, walls per se; on the other, the exercise of jurisdiction by states over the people trying to enter their territory.

6.2 See P. Pallister-W ilkins, 'Bridging the Division: Middle Eastern Walls and Fences and the Spatial Governance of

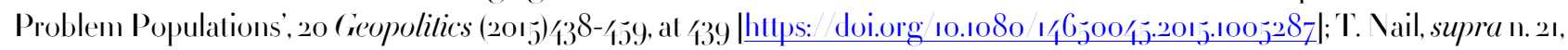
at $119-120$.

63 In this regard, see J. Ramji- Vogales, 'Freedom of Movement of Undocumented Migrants', „̧ Texas Inlernalional Law Journal (2016)เ-17. 
Regarding the former, as seen above, the international courts have specifically ruled on the need for walls to follow internationally accepted border delimitations. They have not questioned the existence of controls as long as they respect those boundaries; ${ }^{6 / 4}$ otherwise, they have declared them illegal. ${ }^{65}$

However, even when walls do adhere to internationally accepted borders, the ECIIIR has recalled the need to respect and preserve human life above and beyond any potential claim to protect the border at all costs. ${ }^{66}$ This could, over time, lead an international jurisdiction, in particular, the ECIIIR, to rule on the compatibility of certain mechanisms, elements or security systems (electrification, concertina wire, etc.) used in the construction of walls with human rights, given that they could be especially harmful and, where applicable, could be considered contrary to the life and physical integrity of the people trying to get past them. In other words, it could lead an international court to rule on the legality of how a border wall or fence is materially constructed, in addition to the legality of the boundary it marks. ${ }^{67}$

With regard to the latter, as far as the exercise of jurisdiction by a state and its potential impact on the fundamental rights of the people trying to cross its borders are concerned, the procedural protection mechanisms established at the international level - in particular, the competent international jurisdictions with regard to human rights - are not always ideally positioned to make this decision. This has proven true with regard to the right to asylum, which is expressly recognized in the American Convention on Ituman Rights ${ }^{68}$ but only implicitly recognized under the European Convention on Human Rights through a broad consolidated interpretation by the ECtIIR of Article 3 thereof, whereby a person protected by the ECIIR - i.e. a person under the jurisdiction of a State Party to it - cannot be returned to another country if there is a risk that he or she might be punished or subjected to cruel, inhuman or degrading treatment. ${ }^{69}$

6, See the case Strelelz, Kessler and Krantzv. Germany, supra n. 13, para. 7t, in which the ECtIIR upheld the legality of the Berlin W all, built along the border agreed by the four powers, holding that "the aim of the Berlin Wall was to protect the border between the wo German States at all costs in order to preserve the GRI)'s existence, which was threatened by the massive exodus of its own population”.

65 In this regard, the IC.J unambiguously affirmed that the mere construction of the security fence on occupied Palestinian territory violated international law because it had been erected "to create a fait accompli on the ground that could well bec ome permanent, in which case ... it would be tantamount to the fact of annexation”. See Advisory Opinion, supra n.12, para. I2I. On this aspect, see Y. Blank, 'Legalizing the Barrier: The Legality and Materiality of the Israel Palestine Separation Barrier', $^{6}$ Texas Inlernational Law Journal (2011) 309-313, available here.

66 In accordance with the terms used by the ECIIIR, the aim of protecting a state's border must be limited and, especially, must respect the need to protect human security such that the border protection does not have an indiscriminate effect or "a categorical nature to annihilate border violators ... and protect the border at all costs". See the case Strelelz, Kessler and Krenz v. Germany, supra 1.13 , paras. $72-73$.

${ }_{67}$ In the same vein, see M. Paz, supra n. 29 , at $60_{5}$.

68 In accordance with Arts. 22.7 and 22.8, whereby: "7. Every person has the right to seek and be granted asy lum in a foreign territory, in accordance with the legislation of the state and international conventions, in the event he is being pursued for political offenses or related common crimes. 8 . In no case mav an alien be deported or returned to a country, regardless of whether or not it is his country of origin, if in that country his right to life or personal freedom is in danger of being violated because of his race, nationality, religion, social status, or political opinions. 9. The collective expulsion of aliens is prohibited."

69 This was the means used by the ECallR to rule on the asylum applications, in addition to Art. 4 of Protocol Vo. A, pursuant to which, "Collective expulsion of aliens is prohibited." 
In this regard, the ECtIIR should be praised for its sensible and progressively broader interpretation of the protection offered under Article 3 . That expansion, and, therefore, the overcoming of that intangible barrier, was accomplished, first, by expanding the protection offered to include non-nationals subject to a state's jurisdiction who cannot be returned to their country of origin due to the risk that they will be tortured or subjected to cruel, inhuman or degrading treatment or punishment, not just in accordance with the five criteria of persecution set forth in the Geneva Convention relating to the Status of Refugees race, religion, nationality, membership of a particular social group or political opinion - but also in proven cases of clear socio-economic deprivation or the existence of a widespread situation of violence in the slate of origin or transit, as in the case of the astlum seekers crowded at the Greek border. ${ }^{70}$

Another way in which this intangible barrier has been overcome is through a progressively more open interpretation of the principle of non-refoulement, which the ECIIIR initially interpreted as a negative obligation not to expel and, later, transformed into a positive obligation for states to protect, further understanding that they should study the asylum application with due diligence, i.e. with due care and within a sufficiently short period of time, especially given the situation of hardship suffered by the applicant, who is entirely in the hands of the state, thus requiring the latter to provide adequate sustenance and shelter. ${ }^{71}$

The ECIIIR has also extended its jurisdiction beyond the strict territory of the States Parties, considering itself competent to rule on the violation of any of the Convention's provisions by any of the contracting parties, even if the violation has occurred outside the physical territory thereof, i.e. beyond the walls or borders of the state in question, as long as it affects an individual who is subject to its jurisdiction. In this regard, the ECIIIR has found this jurisdiction to exist whenever the state's authorities exercise effective control over that individual, whether on land or at sea, especialls in boarding operations and operations to return individuals aboard boats intercepted by authorities in order to prevent them from reaching the state's territory, where they would be entitled to apply for asylum, ruling in this case that there is no physical place beyond the protection of human rights. ${ }^{72}$ Thus, the ECIIIR ultimately clearly condemned so-called "hot returns" precisely in a situation inv olving an assault on one of these fortifications

7o So the ECIIIR noted in its judgment in the case 1. 1.v. Iniled Kingdom, Application \o. 2590/ 07, of 6 August 2008 , stating, in paragraph ${ }_{1}$, that "the Court will not discount the possibility that a general situation of violence in a country of destination will be of a sufficient level of intensity as to entail that any removal to it would necessarily breach Article 3 of the Convention". And so it affirmed shortly thereafter in the case I/SS v. Greece and Belgium, Application No. 30696 og, of 21 January 2011, when it held that "acule financial deprivation" or a situation in which the ass lum seeker "is wholly dependent on State support" and is "in a situation of serious deprivation or incompatible with human dignity" would fall within the scope of Art. 3 ECIIR and, therefore, warrant protection.

7' The ECIIIR thus held, "The Greek authorities have not had due regard to the applicant's vulnerability as an asylum seeker and must be held responsible, because of their inaction, for the situation in which he has found himself ... living in the street ... without any means of provide for his essential needs”. See MSS v. Greece and Belgium, supra n.70, para. 115.

$7^{2}$ Thus, in the Ilirsi Jamaa case, the Court found that jurisdiction is exercised in accordance with Art. I ECIIR by a State Party: "whenever the State through its agents operating outside its territory exercises control and authority over an individual, and thus jurisdiction". See the case I/irsi Jamaa v. Ilalv and Others, Application No. 2776 $6_{5}$ og, of 23, February 2012, paras. 596o. In the same regard, see the cases Georgiav. Russia (I), Application No. 1325. o7,judgment of 3. Julv 201/4; Sharifi and Others

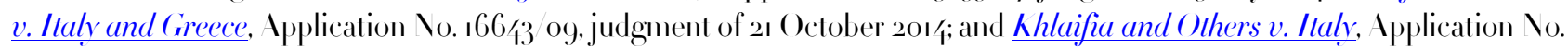
I6,83 12, judgment of 15 December 2016 . 
the Melilla fence - by two men from two African countries, one of which was clearly unstable and plagued by a situation of widespread violence. The wo men were apprehended by the Spanish authorities and returned immediately, without being given an opportunity to identify themselves and apply for asylum as they had wished.73

Vowithstanding the above considerations, the protection offered in the European system remains, in any case, precarious, as this right is not explicitly enshrined in the ECIIR, but rather is a jurisprudential construction that the ECIIIR has gradually - although not always peacefully - imposed on states. In a certain sense, this puts its very existence and jurisdiction at risk, given that, in case of persistent disagreement, a State Party could choose to denounce the ECIIR and abandon this protection system. ${ }^{71}$

That is precisely why it has been argued that the presence of walls and forlifications may largely be due, today and in future, to an overly broad protection of migrants by the international human rights protection mechanisms and systems. According to this argument, given that the exercise of jurisdiction over a person implies his or her presence in a state's territory, using walls to prevent that presence is a legitimate and valid goal for states to prevent the entry of the non-national population resident outside its borders. This drift by international bodies - considered excessively protectionist of human rights would thus encourage the construction of such walls in Europe, which would explain what has happened in the EU in recent years. ${ }^{75}$

Not only does such an assertion seem overly categorical, it also perverts the debate. First, the construction of walls in the world predates the existence of humanitarian crises such as those that Europe has been experiencing since 20n, which were undoubtedly the trigger for the construction of border fences in various European states. ${ }^{76}$ Second, the origin of this case law fav ouring a broad interpretation of

73. See the case 1.I. and X.T.v. Spain, Applications Xos. 8675/15 and 8697/15, of 3 October 2017 , in which the Court found that the fact that the men, upon descent from the wall, were under the physical control of the agents of Spanish authority entailed an act of exercise of jurisdiction by Spain, without going into whether the fence was or was not in Spanish territory, and that the immediate return of the applicants without their prior identification and without allowing them to submit an asylum request constituted a collective expulsion of aliens as prohibited under Art. 4 of Additional Protocol Vo. 4 to the ECIIR.

71 See, in this regard, the statement made by British Prime Minister David Cameron on the subject on at least two different occasions as a result of the ECAllR's various rulings against the $\mathbf{K}$ involving the extraterritorial application of certain ECIIR provisions, in particular, Art. 3, and the possibility of expelling aliens considered to pose a threat to national security: Inaily Mail, 3 June 20г5 ("Our plans set out in our manifesto do not involve us leaving the European Convention on Ituman Rights. But if we can't achieve what we need ... when weve got these foreign criminals committing offence after offence and we can't send them home because of their right to a family life that needs to change. I rule out absolutel nothing in getling that done").

75 See M. Paz, 'Between the Kingdom and the Desert Sun: Muman Rights, Immigration, and Border W alls', 34 Berkeley Journal of Inlernalional Law (2016-1) I-43; and M. Paz, 'The Law of W alls', 28 European .Journal of Inlernalional Law (20172) 6on-62/, who notes that "To foster an honest conversation about absorption capacity, the third necessary step to effect change is to remove human rights courts and quasi-judicial bodies from their central role and make the process much more overtly political" (at 62/1).

$7^{6}$ See, for example, the so-called Edirne wall (Turkey), the primary barrier for Syrians who cannot afford the journey to the island of Kos and try to reach Macedonia on foot. Built in 2013 and costing 3 million euros, it was funded by the EU. With a total length of r2.j kilometres, it mainly affects Svrians, Afghans, Iraqis and Palestinians. See also the walls in the cities of Lesovo and Kravnovo, separating Bulgaria and Turkev, which span a total length of rzo kilometres, whose construction was also funded by the EU amid the humanitarian crisis in the Mediterranean. These walls led to a significant increase in the maritime exodus, as the sea became virtually the only was to reach Europe from Turkes. The separation fence between Serbia and Hungary, likewise a consequence of the closure of the aforementioned paths and affecting those arriving from southern Macedonia and 
the concept of jurisdiction for the purposes of the protection afforded under the ECIIR also predates and is unrelated to the situation that has prompted this response by European states in favour of fortification. ${ }^{77}$ Third, insofar as it is an extremely serious circumstance obliging states to tenaciously defend their national security - where necessary, with walls or fences - and one that has firmly taken root in them, the terrorist threat refers to the emergence of a new and different form of terrorism. It refers to the emergence of a terrorist movement with hitherto unknown profiles, territorial control and power (Daesh) and equally radically different means of perpetrating its altacks, particularly with the rise of foreign terrorist fighters. It moreover has to do with the similarly unprecedented success rate of the Islamist terrorist attacks accomplished by this new terrorism using those new means of perpetrating attacks. And, fourth, some states not only try to keep these people off their soil, but also intervene by establishing obligations in the territory of third states, as will be seen below.

Finally, it should be recalled that the declaration of a state of emergency also constitutes an intangible border, set up against these massive population displacements towards Europe of which the European states are so wary. It requires insoking Article r ECIIR and temporarily repealing the Convention's application in accordance with a provision that all the sovereign states' legal systems include in their respective law, allowing them to declare a state of emergency in the case of an imminent threat to their very existence as a state. ${ }^{-8}$ Even though Article 3 is non-derogable, even in case of a state of emergency, the invocation of this circumstance by States Parties in relation to security nevertheless creates another indirect barrier to the protection of displaced peoples.

Is for the walls built outside Europe and their impact on the rights of persons, the winding, irregular and intrusive path of Israel's so-called "security fence" clearly undermines and warps the enjoyment of the fundamental rights and freedoms of the Palestinian people, including: access to work; enjoyment of private property and exploitation of centuries-old farmland; access to healtheare; access to water (the largest water reserves are on the Israeli side of the wall); connection with other Palestinian zones, which have been turned into islands cut off from any other Palestinian territory; or the possibility to trade with other countries or communities. ${ }^{79}$ This crucial impact that de faclo prevents Palestinians from enjoying most of their fundamental rights has also been highlighted and denounced by the Special Rapporteur, Martin

Bulgaria, comprises a total of 135 kilometres of fencing standing 4 metres tall. Abuses by the mounted police of the ultraconservative Hungarian government have been documented along it, and Itungary later asked the European Commission to co-finance it. The request was denied. Finally, see the wall between Slovenia and Croatia, with a border spanning 67o kilometres, which will not be entirely fortified, on which construction began in late $20 \operatorname{rg}_{\mathrm{j}}$ It is intended to prevent the displacement of people arriving to their territory from Greece especially towards Austria and Germany; however, in practice it has caused serious environmental damage.

77 This case law began with the case Loizidou v. Turkev, (Preliminary Objections), Application \o. $153^{18} 89$, of 23 March 199.5, and was maintained in the following cases: Loizidou v. Turker (Merils), Application \o. $1533^{8} 89$, of 18 December 1996 , para. 56 ; and Cyprus v. Turkey, Application Vo. 25781 94, of ıo May 200 I.

$7^{8}$ Three States Parties to the Convention recently maintained the repeal of Article ${ }_{5}$ ECIIR: France, Turkey and $U$ kraine. See hllps: coe.int en web) conventions.

79 Statisties from the Israeli Information Centre for Ituman Rights in the Occupied Territories (B'Tselem), available here. 
Scheinnin, in his fifth report on respect for human rights and the fight against terrorism, ${ }^{80}$ which, in theory, was the ultimate reason for the wall.

However, the clearest and most obvious example of these walls' "inhumanity" and the blatant violations they entail of certain fundamental rights may be the wall dividing Mexico from the US and the latter government's fight against illegal immigration. The construction dividing these wo countries is the most comprehensive example of a tangible and intangible barrier to the movement of people and the most radical attempt to regulate and manage a problem of international dimensions from an obstinately unilateral perspective that presents immigration as a national security emergeney in the face of serious crime. $^{81}$

Because the executive orders and countless other orders, guidelines and memoranda adopted by the Trump administration against immigration offer an extensive catalogue of restrictive, repressive, persecutory and deterrent measures not only against immigration, but also against application for any form of international protection, they are an attack on human dignity. ${ }^{{ }_{2}}$ The wo executive orders, which sought to make good on one of President Trump's main campaign promises, make the construction and reinforcement of the US-Mexico border wall their main objective. To this end, they called for, and continue to call for even today, extraordinary funding in terms of both nature and quantity which the president turned into a national emergency, triggering the longest government shutdown in US history, and which he finally partially obtained from the Pentagon, after a close decision by the Supreme Court. ${ }^{8_{3}}$

As seen earlier, the philosophy of resuming the construction and reinforement of the wall reflects the conception of immigration as a form of crime per se, as the new regulations have transformed what was once only an administrative offence into a criminal one. However, beyond this starting point, the most unfortunate aspect is the atlack it constitutes on certain basic principles of the rule of law and on a series of human rights long-established in the international system.

With regard to the former, the new system designed in Trump's execulive orders largely strips the court system of its ability to intervene, transferring the power to decide on the study and concession of any form of protection to the border police, although not to specialized personnel, protection officers or immigration judges. At the same time, it allows individuals to be detained merely "on suspicion" of violating federal or state law, which includes unauthorized entry. 8 i

8o See Doc. IIRC Report on Economic, Social and Cultural Rights in the Contevt of Countering Terrorism (2007), A IIRC 6 17. In this regard, see R. Busbridge, The wall has feet but so do we: Palestinian workers in Israel and the separation

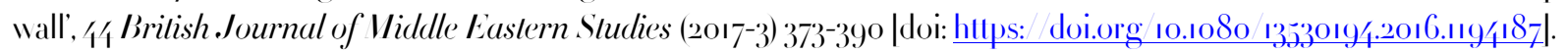

${ }^{8}$ As for the declaration of a national emergency by President Trump, see Reuters, "Trump vows “V ETO!" after bipartisan Senate rebuke on wall', 1/ March 2019 .

$8_{2}$ See D. García-Rieci, 'El muro en la frontera Méxieo-Estados Unidos: un atentado a la dignidad humana', ıo Derechos Ilumanos Véxico (2009) 1/17-ı6/1.

83 See The Guardian, 'Supreme Court allows Trump to use $\$_{2 . j}$ bn in Pentagon funds for border wall', 26 .July 2019 ; and The New York: Times, 'Supreme Court Lets Trump Proceed on Border W all', 26 July 2org. A one-paragraph-long .-1o-4 ruling was finally adopted, allowing President Trump to access funds from the Pentagon whilst a district court decides on the merits.

8, See Vational Immigration Justice Center, Annotated Border Immigration Enforement Executive Order, Section 2 (b). 
The new regulations adopted by the Trump administration add a further restriction to these obstacles, so-called "expedited removal”, a procedure allowing officials from the Department of IIomeland Security (DIIS) to summarily remove noncitizens without affording them a hearing before an immigration judge or a review by the Board of Immigration Appeals (BI A). Additionally, the IIomeland Security Secretary has the authority to apply expedited removal to any individual "apprehended at a place other than a port of entry, who is inadmissible under either of those grounds, has not been admitted or paroled, and cannot show that he or she has been continuously present in the US for two or more years". ${ }^{85}$ Expedited removal differs deeply from removal proceedings before an immigration judge as in the latter case, noncitizens may have an attorney represent them, may apply for relief from removal and are entitled to substantial due process guarantees, in accordance with the requirements of the Fifth Amendment. Execulive Order ${ }_{37}{ }^{6} 7$ instructs the Itomeland Security Secretary to apply this existingprocedure to the fullest extent of the law, thereby further depriving noncitizens of this fundamental right, as stated by Judge Pregerson in his dissenting opinion in U.S. v. Peralla-Sanchez. ${ }^{87}$ At the same time, it blurs the separation of powers, stripping immigration judges of one of their main powers.

Moreover, depriving certain immigrants in different states (e.g. Washington or Vinnesola) of their temporary protection status, and, therefore, subjecting them to immediate removal, affects the funding that states receive from the federal government to cope with medical care, education, employment, business, family relations, ele., which is calculated according to their respective populations. In light of this situation, US courts have granted a temporary restraining order (TRO) against certain actions (antiimmigration measures) taken by the executive, viewing them as a further example of invasive activity by the executive branch with regard to the other two branches of government as far as immigration regulation is concerned. ${ }^{88}$

Several states filed the same claim with domestic courts after the US executive's attempt to include a question on citizenship status in the 2020 ten-year census questionnaire that would likely make most nonUS nationals reluctant to answer it and, thus, fail to take part in the census. According to some states (the plaintiffs), this would deeply alter the final result of the census, whose main purpose is to guide the allotment of congressional seats to the states based on their respective populations. As has been pointed out, the federal government also relies on census data to determine how to distribute billions of dollars in funding each year, including funds for Medicaid, Medicare Part B, the Supplemental Nutrition Assistance Program and the Construction Program. Additionally, the most affected states would be those with the

8 Ibid., at 2.

86 See Section I (c) of Execulive Order 13767.

${ }^{8}{ }_{7}$ In particular, the judge stated that: "|T|he deportation process can begin and end with a CBP officer untrained in the law ... There is no hearing, no neutral decision-maker, no evidentiary findings, and no opportunity for administrative or judicial review. This lack of procedural safeguards in expedited removal proceedings creates a substantial risk that noncilizens subjected to expedited removal will suffer an erroneous removal." See L.S. 1. v. Rufino Peralla-Sanchez, case no. 1/4-50393,

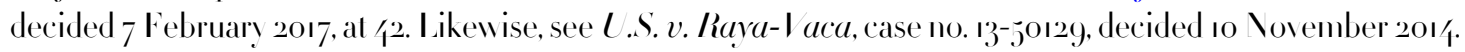

88 See Slale of II ashinglon el al. v. Donald J. Trump al al., case no. C17-or/1JILR, decided 3 February 2017. 
highest number of non-U S-national residents, ${ }^{89}$ which have traditionally been more permissive and open to immigrants. Consequently, the move to include a question on citizenship for the first time in the history of the US census would additionally hit more open states harder and, thus, decrease the Democratic opposition in the US Congress.

Returns at the border without allowing the submission of asylum or protection applications also clearly violate the obligation of non-refoulement agreed under Article 33 of the Refugee Convention, to which the US is a party. This fact is not remedied by the sy stem of returning applicants to the other side of the border to wait for their asy lum applications to be studied or by the fact that the US Sexecutive has begun to sign international agreements with third countries with a view to outsourcing the work of intercepting Central American migrants to the US. This violation is compounded by the imposition of the removal at all costs of immigrants who illegally enter the country and the obligation for asylum seekers to stay on the other side of the border whilst their asylum status is decided, as a deterrent to migration to the $\mathrm{CS}$, as well as the elimination of the possibility of obtaining immigration "parole", i.e. of temporarily entering the US despite lacking a visa or green card, as had previously been possible.9"

Additionally, to the extent that the preferred course of action with regard to migrants is detention, the fundamental right of access to legal assistance to defend, for example, their innocence or their petition for asylum or protection, which should moreover occur within a specified amount of time and which had already been difficult, has become virtually impossible, ${ }^{91}$ especially if the applicant is not allowed to enter the country but rather must wait on the other side of the border until his or her status can be decided. In this regard, and in addition to this new harmful procedure for dealing with asylum seekers, other complementary measures have been taken to support the Trump administration's new immigration policy, the so-called "zero-tolerance" policy. Thus, the Homeland Security Secretary took a series of decisions following the issue of President Trump's execulive orders on immigration, consisting of terminating the agreed temporary protected status for certain nationals arriving from Central American countries (El Salvador, Nicaragua and Maiti) and from Africa (Sudan) about whom President Trump’s public declarations had veered dangerously close to racism. Lawsuits in U S district courts have demonstrated not only how deeply polluted those decisions are by an openly declared anti-immigrant sentiment, but also that courts have found them to be discriminatory and contrary to the Equal Protection Act. Apart from this racially discriminatory immigration policy that runs contrary to the US constitution and Fifth Amendment

$8_{9}$ See Stale of California el al.v. II ilbur Rose el al. and Cilvof San.José el al.v. II illbur Rose al al., cases nos. 18-cv-01865RS and; I8-cv-2279-RS, decided i7 August 2018. See also Robvn Kravilzel al. v. I niled Slales Deparlment of Commerce and La U nion del Pueblo Enlero el al. v. IV ilbur Rose el al., cases nos. G.JII-18-10,1 and G.JII-18-1570, decided 28 I December 2018 ; and Slate of Tew York el al. v. I niled Slales Department of Commerce el al. and Wew York: Immigration Coalition el al. v.

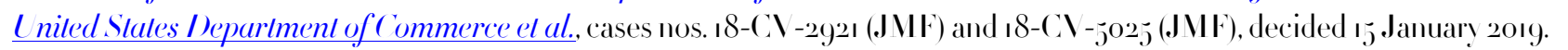

$9^{\circ}$ See National I enture Capilal Associalion el al.v. Elaine Duke, Acling Secrelary, U.S. Deparlment of IIomeland Securily, el al., Civil Action Vo. 17-1912 (JEB), decided I December 2017; and. Ansh I Damus el al. v. Kirsljen Vielsen, Secrelary of the Department of Itomeland Securily, el al., Civil Action Vo. 18-578 (JEB), decided 2 July 2018.

9r See I. Eagly and S. Shafer, Access to Counsel in Immigration Court, American Immigration Council; and 'Asvlum under Threat: Impact of President Trump's Immigration Execulive Orders and the Department of I Iomeland Security's Memoranda on Asslum Seekers', Ituman Rights First, Fact Sheet, February 2017. 
rights themselves, the material consequences include the expulsion of these nationals from the country. This indispulably causes irreparable harm and great hardship, as beneficiaries who have lived, worked and raised families in the US (many for more than a decade) would be subject to removal (refoulement, in fact, to places whose violence they once fled) and be uprooted from their homes, jobs, careers and communities. Furthermore, their US-born children would have to choose between staving alone in the US (the only country and community they have known) or leaving with their parents for countries to which they have few to no ties and which might not be safe..$^{2}$ The spectre of racism has also cast its shadow over the adoption of some of the Trump administration's travel bans, whether collective (the seven-country ban) or individual, as in the cases of II ashinglon v. Trump and Trump v. I/awaï.93

In short, the harmful effects of the physical wall built by the US on its border with Mexico have been compounded, from an anthropocentric perspective, by numerous violations of fundamental rights guaranteed by the US Constitution, as well as various international law obligations by which the country is bound, in the most thorough example of how a tangible and intangible barrier has been built and reinforced between two states.

Last but not least, a dramatic situation persists with regard to minors, in particular those who left their home countries with their parents and have since become unaccompanied minors, as the new poliey at the US southern border consists in separating adults from their underage children, so that parents can be detained for unauthorized entry and be subjected to criminal proceedings or put in immigration facilities in accordance with the aforementioned zero-tolerance policy. Although the new regulation ${ }^{91}$ is claimed to be intended to preserve family units whilst also ensuring rigorous enforcement of migration laws, measures were not put in place to enable communication between the government agencies responsible for detaining the parents and those responsible for housing the children or ready communication between the separated parents and children themselves. No reunification plan was decided or in place, and families, including some with very young children (e.g. an i8-month-old baby), have been separated for months across distances of thousands of miles, as the federal government failed to enough housing for migrant families. The practice has resulted in the casual, if not deliberate, separation of families, including those that lawfully presented themselves at the port of entry seeking asylum. Some parents have even been deported without their children, who remain in government facilities in the $\mathrm{US}$. This inhumane practice has also been condemned by US courts. ${ }^{95}$

92 See Crisla Ramos el al.v. Kirstjen Vielsen el al., case Vo. 18-c-oryjy-E MC, decided 3 October 2or8; Casa de Varvland, IXC., el al.v. Donald.J. Trump, in his official capacily as President of the I niled Stales, el al., case No. G.JII-18-8 4.5, decided 18 Vovember 2018; East Bav Sancluarv Covenant el al. v. Donald .J. Trump el al., case Vo. I8-cv-o68ı-JST, decided 19 December 2018; and Innovalion Law Lab el al.v. Kirsljen Vielsen el al., case Vo. 19-cr-oo807-RS, decided 8 April 2019.

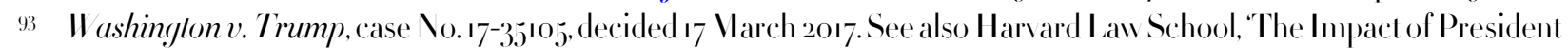

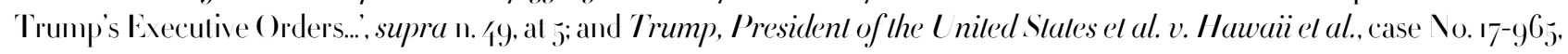
decided 26 June 2018.

91 See Execulive Order, Affording Congress an Opportunity to Address Family Separation, 20 June 2018.

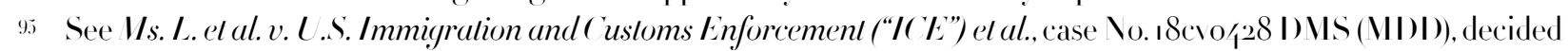
26 June 2018. 


\section{(D) SOMECONCLUDI\GREMIRKS}

Although the consequences of the main examples discussed in this study (Europe, Israel/Palestine, India Pakistan and, especially, Mexico the US) differ depending on the different contexts in which they occur, there are important similarities in the arguments used to build and justify these walls; what they mean in relation to the political identity, sovereignty and territory of each state; how they affect the lives of the border populations; and their negative impact on people. Recourse to such measures, the way they are used and their consequences usually lead to violations of international obligations and the transformation of essential concepts of contemporary international law.

However, the mutual understanding, respect and trust that ultimately comprise the basis for international peace and stability are not forged or maintained by building separation walls that disrupt communication, contact and all facets of life and that moreover use defence systems banned under international law, as is clearly the case of walls reinforeed with anti-personnel mines, which are banned under the Otlawa Treaty. Walls ensure a continuous state of mutual distrust, alertness and, in the end, insecurity for the populations they separate, and they are used to justify all types of abuses and violations of states' international obligations. Therefore, they are not a valid solution for any of the problems they purport to solve.

Today's growing "wallmania" is nothing other than a new way of understanding international law and of regulating international relations from a perspective that is not only unilateralist but also strictly "security"-based and isolationist. This perspective is wearing away at basic constitutional principles of contemporary international law, whilst at the same time fuelling regressive reinterpretations of state sovereignty, human rights, the use of force and normal neighbourly relations between states. In short, all of this leads to a denial of the very concept of contemporary international law as a cosmopolitan system committed to a set of values and protecting the individual. By disrupting dynamic cross-border flows and preventing contact between different societies, in a word, preventing them from mixing, walls inevitably lead to cultural impoverishment and the unilateralization of international and European law, resulting in their dehumanization and the loss of their values. 